\title{
Influence of Organizational Climate Towards Polyglot In- donesia Members Intercultural Communication Skill Mediated by Self Motivation
}

\author{
Nararia Hutama Putra*, Joko Sutarto, Amin Yusuf \\ Universitas Negeri Semarang, Indonesia \\ *Email: nararia92@gmail.com
}

Submitted: 21 October 2020. Revised: 13 November 2020. Accepted: 13 February 2021

\begin{abstract}
Polyglot Indonesia is a form of nonformal learning organization that concerns on developing the intercultural communication skill of its members. This study shows how the organization element (organizational climate) helps to develop intercultural communication skill of the members. The aim of this study is to analyze the influence of organizational climate mediated by self motivation towards intercultural communication skill of Polyglot Indonesia members. This study is categorized as ex-postfacto study with quantitative approach. The population of this study are 152 members of Polyglot Indonesia who have been joining the whatsapp group of Polyglot Indonesia All chapters and the sample that used in this study are 110 respondents. The data were collected through online questionnaire. The data analysis was using SPSS 21.0 Software. The results and conclusion of this study are, (1) $t$ value regression of $\mathrm{X}$ variable towards $\mathrm{Y}$ is 2,122 and significance level is 0,036 , which means there is a significant direct influence on organizational climate towards intercultural communication skill of Polyglot Indonesia members; (2) t value regression of $\mathrm{X}$ variable towards $\mathrm{Z}$ is 2,957 and significance level is 0,004 , which means there is significant direct influence on organizational climate towards self motivation of Polyglot Indonesia members; (3) t value regression of $\mathrm{X}$ variable towards $\mathrm{Y}$ mediated by $\mathrm{Z}$ is 2,333 and significance level is 0,05 , which means there is a significant indirect influence on organizational climate mediated by self motivation towards intercultural communication skill of Polyglot. Indonesia members. This study new finding shows that self motivation strengthened the impact of organization element in achieving organization goal as nonformal learning organization. The study benefit for the science development is to show a form of nonformal learning through learning organization and enhance the knowledge of the core value of nonformal learning itself.
\end{abstract}

Key words: Intercultural Communication, Organization Culture, Self Motivation,Polyglot Indonesia, Learning Organization

How to Cite: Putra, N. H., Sutarto, J., \& Yusuf, A. (2021). Influence of Organizational Climate Towards Polyglot Indonesia Members Intercultural Communication Skill Mediated by Self Motivation. Journal of Nonformal Education, 7(1), 14-22.

DOI: http://dx.doi.org/10.15294/jne.v7i1.26790

\section{INTRODUCTION}

Learning organization is organization that provides opportunities for those who are part of the organization to participate in learning, to expand their capacities and abilities according to what is expected to be realized. Learning organization concerns to stimulate learning, which becomes its central activity (Palos, 2016) . Learning organization could be in the form of formal embodied in organization or official agency that is legally binding. And learning organization can be tangible also as non-formal, growing up in the middle of the community and involving emotional aspects.

Polyglot Indonesia is a non-formal learning organization that focuses on community development by developing intercultural communication skill through foreign languages and multicultural social patterns. Polyglot Indonesia has been officially recognized and registered by the Ministry of Law and Human Rights of the Republic of Indonesia with decree number AHU-0002116.AH.01.07. Year of 2015. However, despite being legally registered, Polyglot Indonesia is still classified as a non-formal learning organization. That is because Polyglot Indonesia takes the form of community organizations that is emotionally binding and voluntary.

As nonformal learning organization, one of the priorities goals of Polyglot Indonesia is human resource development, and the core of its principal is to motivate human beings to work together humanely (Nongkeng, 2012). Human resource development is very important to organization in achieving its goal (Nurwidyanti, Marnis, \& Marzolina, 2015). It is manifested through language learning to facilitate the self-improvement of its members, language is believed has major role in intercultural communication (Makmur, Kuswarno, Novianti, \& Syafirah, 2018) that is become Polyglot Indonesia concerns. This is clearly stated in the first point of the organization's mission "Facilitating language practice activities that support personal development, career and education". It is clear that Polyglot Indonesia's big mission is to play an effective role in the internal development of organizational human resources. However, a good organization will be affected by good team who works behind it (Raharjo, Suminar, \& Mu'arifuddin, 2016).

Polyglot Indonesia is a language learning cultural hub organization, as it is stated that language and 
culture are integrated and can be separated (Santoso, 2012). The development of intercultural communication skill (ICS) is an effort of this organization to facilitate the development of its members. Polyglot Indonesia has been initiating learning activities for its members with variety of fun learning approaches. Non-formal learning activities carried out so far include monthly meet ups, language classes, discussions, seminars and information exchange and social networking around careers, personal growth and education. All activities are carried out free and voluntary. This might be the way how organization manifesting the empowerment role for its members (Lincoln, Travers, Ackers, \& Wilkinson, 2002).

Efforts to develop intercultural communication skill (ICS) members of Polyglot Indonesia, are based on the thought of the need to prepare a forum that able prepare human resources who are ready to face open competition and have global mindset that is no longer limited by national borders and time zones. In addition, Intercultural communication skill could be interpreted as the ability to communicate interculturally to exchange information effectively with other people who have different cultural background (Darmojuwono, 2007). Currently it is also important to better understanding how learning in international contexts (Covert, 2014) as globalization is happening and supporting open competition for whoever in this world. Hence, the ability to communicate mindfully and skillfully unlimited by zones, race and cultural boundaries is very needed (Kerssen-griep \& Eifler, 2008).

Intercultural communication skill is stated to be the most desirable ability after a person graduates from formal education in this globalization era (Krajewski, 2011). Because of global interaction and cultural diversity become prominent, intercultural competence gains more attention (Chang, 2007). It is also believed that the Intercultural Communication Skill is needed in society to create a better society which peaceful and harmony (Sukirman, 2016).

Then, as a learning organization there are some aspects that influences the development of the capabilities of organization members is the routines created to learn together by organization (Dixon \& Dixon, 2017) and also the leadership personality of organization (Langford, Dougall, \& Parkes, 2017). Those can be embodied through the organizational climate (OC). Organizational climate (OC) is believed able to influence the organization in achieving organizational dreams. Every person who joins an organization must have expectations for the organization, organization and person inside organization meet each others needs (krist off in Behery, 2009). The success or fail- ure of the organization is also determined by the success or failure of the organization to embody the expectations of its members.

Organization is complex it can be concluded as well that the complexity in organization especially in the division of roles have the big effect to the organization (Dhondt, Pot, Kraan, Dhondt, \& Pot, 2014). As the element of organization, climate organization will be affected as well as the expectation of its members. The expectation that makes someone join a language organization such as Polyglot Indonesia is to improve their cultural competence (Fung, Lo, Srivastava, \& Andermann, 2012), in this topic it refers to ICS. A good and appropriate Organizational Climate is expected to make these expectations can be realized.

Organization is complex and organizational climate is an important component in organizational studies (Nuseir, Nusair, \& Rumy Arora, 2012). Organizational climate is always present in every organization and has a big influence on the behavior of members of the organization. Likewise in achieving organizational goals, a positive organizational climate will produce positive behavior. It inline with Buvik's statement that can be concluded Organizational Climate strength (organization trust climate) will affect the performance of organization members and also organization itself (Buvik \& Tvedt, 2016). As a part of work or organization environment Organizational Climate is believed give the significant impact on organization members performace as part of organization (Enny, 2015), it happen because organizational climate will also affect the attached feeling of the members, Affectively attached by members will give benefit for the organization itself (Suliman \& Iles, 2000).

Positive behavior from members of the organization will facilitate the organization in realizing the expectations of the people in it, behavior was strongly related to strong social norms (Dodoiu, 2015). In learning organizations such as Polyglot Indonesia believes that members creativity relate to resolve critical problems, and it occurs by integrating diverse knowledge at multi level organisational units (Furukawa, 2016). Good collective work also will bring good benefit to organization achieve its goal (Tongo \& Tongo, 2015), In this study will focus on the development of intercultural communication skill (ICS) as one of its main objectives and part of crossunderstanding (Meslec \& Graff, 2015). So that the application of a good organizational climate is expected to influence these objectives can be achieved.

There are the relations between different types of energy in the heart of collective energy (Kahrobaei, 
2016), and it helps the organization to pursue its goals. However ICS which is not only offered by those that arise from the organization. Internal factors that emerge from the person become crucial enough to be considered if related to personal development. Moreover if OC applied with motivation from the organization members it will bring more benefits. Self motivation (SM) supports being able to help the organizational climate in conditions of supporting businesses in developing ICS for the better, as it is implied that self motivation of members has impact on organizational climate which part of organization environment according to theory $\mathrm{z}$ character based education (Wasono, Soesanto, Samsudi, \& Sutarto, 2015).

Positive motivation will be contrary to the performance of members who will be positive also against organizational goals and also applies vice versa (Sukaryanti, 2016). With regard to individual of Polyglot Indonesia members, priorities in efforts to improve their intercultural competence are urgently needed by the motivation of its members. In fact, someone will definitely be actively involved in a compilation organization, considering that this organization is still relevant and able to accommodate its personal mission. The members will be more satisfied of the organization if they able create more developmental space (Derksen, Caluwé, Rupert, Simons, \& Derksen, 2014). According to this background the author will discuss the topic of "The Influence of Organizational Climate Towards Polyglot Indonesia Members Intercultural communication skill Mediated by Self motivation".

\section{METHODS}

This study used a quantitative approach and categorized as an ex-post facto research. The following research design places organizational climate (OC) as the independent variable (X) and intercultural communication skill of members of Polyglot Indonesia (ICS) (Y) as the dependent variable, and the self motivation of the members $(\mathrm{SM})(\mathrm{Z})$ as an intermediate variable (intervening/mediating variable).

The population in this study were all administrators and members of organizations scattered throughout the territory of Indonesia and around the world but united in the whatsapp group PI ALL CHAPTER, the total active population was 152 people. Sampling in this study uses a simple random sampling technique that is taking a random sample without regard to levels in the population (Sugiyono, 2012: 57). Determination of the sample is based on calculating the number of samples with the Slovin formula with an error tolerance level of $5 \%$. So the results of the sample are 110 members (members). With the criteria of Polyglot Indonesia members who have been and/or are still actively contributing to activities both online and offline. It is proven by joining in the PI ALL Chapters group.

There are two research techniques used in collecting data, namely 1) questionnaire technique; 2) documentation techniques. The questionnaire was distributed online in 2020 and in the form of a Checklist considering that Polyglot Indonesia members were scattered in various regions of Indonesia and several countries. The questionnaire made refers to the Likert scale with a range of scores from 1-5 where a score of 5 states strongly agree and a score of 1 states strongly disagree. The research questionnaire consisted of 14 questions for ICS, 8 questions for $\mathrm{OC}$ and 9 questions for SM which were tested for its validity and reliability. The questionnaire was used to obtain data on the influence of organizational climate, assisted by self motivation on communication skills at Polyglot Indonesia. Second, using documentation techniques to collect various documentation from various sources.

There are three data analysis techniques used in this study: 1) descriptive statistical analysis; 2) classic assumption test; and 3) hypothesis. The three data analysis techniques were chosen because, 1) Descriptive statistical analysis in this study was intended to get a picture of the spread of research results from organizational climate variables (OC) $(\mathrm{X})$, self motivation (SM) (Z) and intercultural communication skill (ICS) (Y); 2) test the classical assumptions to ensure that the data obtained are consistent and unbiased data. The classic assumption tests that used in this study include normality test, multicollinearity test, heteroscedasticity test, and linearity test; 3) hypothesis testing is used to see whether the hypothesis that used in the study is accepted or rejected. Hypothesis testing using linear regression, path analysis (path analysis) and sobel test (sobel test). The hypothesis that will be used in this article are three, namely: 1) Hypothesis 1 (H1), organizational climate directly influences the intercultural communication skill of members of Polyglot Indonesia; 2) Hypothesis 2 (H2), Organizational climate directly influences the self motivation of Polyglot Indonesia members; 4) Hypothesis 3 (H3), Organizational climate has an indirect effect on intercultural communication skill of Polyglot Indonesia members through self motivation. The equation model which used in this article is as follows: 


$$
\begin{aligned}
& \mathrm{Y}=\alpha+\beta 1 \mathrm{X}+\beta 3 \mathrm{Z}+\mathrm{e} 1 \\
& \mathrm{Z}=\alpha+\beta 2 \mathrm{X}+\mathrm{e} 2 \ldots \ldots
\end{aligned}
$$

\section{RESULTS AND DISCUSSION}

\section{Results of Descriptive Statistics}

The results of the study are described in the form of descriptive analysis to explain the variables used in this study, namely: organizational climate (OC) as $(\mathrm{X})$, self motivation $(\mathrm{SM})$ as $(\mathrm{Z})$ and intercultural communication skills (ICS) as Y. The following are translation table of descriptive analysis of the three variables.

Table 1. Descriptive Result

\begin{tabular}{lll}
\hline Variable & Mean & Category \\
\hline ICS & 57.54 & Agree/ High \\
OC & 32.61 & Agree/ High \\
SM & 36.37 & Agree/ High \\
\hline
\end{tabular}

According to table 1 shows descriptive analysis of this study can be seen which states that the average intercultural communication skill (ICS) of Polyglot Indonesia Members are at 57.54 which is included in the agreed category. Organizational climate (OC) on average 32.61 also included in the agreed category. Then, self motivation (SM) is at an average of 36.37 which is included in the agreed category as well. The purpose of table 4.1 shows Polyglot Indonesia members agree that after participating in Polyglot Indonesia has experienced improving their intercultural communication skill (ICS). They felt satisfaction after joining Polyglot Indonesia as evidenced by an average of 57.54 in the agreed or high category. This means that on average members agree that there is improvement in their intercultural communication skills.

Furthermore, it can also be seen from the descriptive analysis, those members feel the organizational climate that is applied together with every form of activity and program at Polyglot Indonesia helps in their personal improvement. This is proven by an average of 32.61 in the agreed or high category. This indicates that organizational climate plays an important role in achieving members personal development.

Based on descriptive analysis as well, Polyglot Indonesia members believe that self motivation (SM) plays an important role in the success of their selfdevelopment as part of the learning organization. Proven by the average of 36.37 which also reached the agreed or high category.

\section{Results of Classic Assumption Test}

This study also used a classic assumption test consisting of normality test, multicollinearity test, heteroscedasticity test, and linearity test:

\section{Normality Test}

Normality test aims to see whether in the regression model, confounding or residual variables have a normal distribution (Ghozali, 2013: 164). The basis for decision making in the normality test of this study is that data are normally distributed if the significance level of the probability produced is bigger than 0.05 (Asymp.Sig>0,05). In this study conducted 2 times normality tests, namely with ICS as a dependent variable and with SM as the dependent variable. So the results are as follows:

Based on the normality test that have already conducted it can be concluded that the data used in this study are normally distributed using both ICS and SM as the dependent variable. This is evidenced by the value of the significance level of probability bigger than 0.05 .

\section{Multicollinearity Test}

Multicollinearity test aims to see whether the regression model really has a relationship of independent variables. Multicollinearity will be seen from the tolerance value (tolerance value) $>0.1$ and VIF $<10$. The following is a summary of the results of the multicollinearity test of this study which is realized in tabular form as follows:

\begin{tabular}{|c|c|c|}
\hline Regression Model & Tolerance & VIF \\
\hline $\mathrm{ICS}(\mathrm{Y}) \leftarrow \mathrm{OC}(\mathrm{X})$ & 0.394 & 2.539 \\
\hline $\mathrm{ICS}(\mathrm{Y}) \leftarrow \mathrm{SM}(\mathrm{Z})$ & 0.271 & 3.696 \\
\hline $\mathrm{SM}(\mathrm{Z}) \leftarrow \mathrm{OC}(\mathrm{X})$ & 0.426 & 2.346 \\
\hline
\end{tabular}

Table 2. Multicollinearity Test

According to data in the Table 2, it was found that the tolerance value of $\mathrm{OC}(\mathrm{X})$ is 0.394 and $\mathrm{SM}(\mathrm{Z})$ is 0.271 which means both $X$ and $Z>0.1$. Whereas from VIF it was found that VIF OC (X) is 2.539 and VIF SM (Z) is 3.696 which means VIF both $\mathrm{X}$ and $\mathrm{Z}$ $<10$. So it can be concluded that the research data using ICS as dependent variables are free from multicollinearity.

According to data in the table 2 as well, it was found that the tolerance value of $\mathrm{OC}(\mathrm{X})$ is 0.426 which means $X>0.1$. Whereas from VIF it was found that VIF OC (X) is 2.346 which means VIF X $<10$. So it can be concluded that the research data 
using SM as dependent variables are free from multicollinearity as well.

\section{Heteroscedasticity Test}

Heteroscedasticity test is a test conducted to see in the regression model whether there is an inequality in variance from residual observations to other observations. It is called heterokedasticity if the variants are different. A good research data model is data that do not occur heteroscedasticity (Ghozali, 2013: 139). This study uses glacier test to determine whether heterocedasticity occurs or not. Heteroscedasticity will be seen from the sig value is bigger or smaller than 0.05 . Following are the results of this study with heterocedastisity test.

Table 3. Heteroscedasticity Test

\begin{tabular}{|c|c|}
\hline Regression Model & Sig \\
\hline $\mathrm{ICS}(\mathrm{Y}) \leftarrow \mathrm{OC}(\mathrm{X})$ & 0.279 \\
\hline$) \leftarrow S M(Z)$ & 0.32 \\
\hline $\mathrm{SM}(\mathrm{Z}) \leftarrow \mathrm{OC}(\mathrm{X})$ & 0.718 \\
\hline
\end{tabular}

According to data in the table 3, it was found that significance value of OC $(X)$ is 0.279 and $\mathrm{SM}(\mathrm{Z})$ is 0.321 which means both $X$ and $Z>0.05$. So it can be concluded that the research data using ICS as dependent variables are free from heterroscedasticity. Heteroscedasticity test was also performed with SM as the dependent variable. Following is the result of this study with SM as the dependent variable.
According to data in the table 3 , it was found that significance value of $\mathrm{OC}(\mathrm{X})$ is 0.718 which means both $\mathrm{X}>0.05$. So it can be concluded that the research data using SM as dependent variables are free from heterroscedasticity as well.

\section{Linearity Test}

Linearity test is a test used to see whether the independent variable as a predictor has a linear relationship or not with the dependent variable. Linearity tests were performed between OC (X) with ICS (Y), SM (Z) with ICS (Y), and OC (X) with MD (Z). and the results of the linearity test show that $\mathrm{X}$ and $\mathrm{Y}$ have a significance value of 0.000 ; while $\mathrm{Z}$ and $\mathrm{Y}$ have a significance value of 0,000 ; As for the significance value of $\mathrm{X}$ and $\mathrm{Z}$ is 0,000 as well.

Requirements for testing data criteria are called linear if the significance value is less than $<0.05$, which means that there is a linear relationship. Based on the results of linearity tests $\mathrm{X}$ and $\mathrm{Y}, \mathrm{Z}$ and $\mathrm{Y}$ and $\mathrm{X}$ and $\mathrm{Z}$ all three have a significance value of 0,000 . So it can be concluded that this research data is linearly related.

\section{Hypothesis Test}

The first multiple linear regression model in this study was tested using path analysis. Following are the results of path analysis using ICS (Y) as the dependent variable.

Table 4. Regression Result Summary (ICS as dependent Variable)

\begin{tabular}{llllll}
\hline Regression & Variable & $\begin{array}{l}\text { Regression } \\
\text { Coefficients }\end{array}$ & S.E & T & Sig \\
\hline ICS as Dependent Variable & Constant & 14.392 & 2.591 & 5.556 & 0.000 \\
& X & 0.214 & 0.101 & 2.122 & 0.036 \\
& Z & 0.449 & 0.118 & 3.801 & 0.000 \\
& $\mathrm{R}^{2}: 0.740$ & E1=0.509 & & & \\
& t-table: 1.66 & & & & \\
SM as Dependent Variable & Constant & 1.381 & 2.128 & 0.649 & 0.518 \\
& X & 0.236 & 0.080 & 2.957 & 0.004 \\
& $R^{2}: 0.729$ & E2=0.520 & & & \\
& t-Table: 1.66 & & & & \\
\hline
\end{tabular}

According to the multiple regression test table of the first path analysis in this study, the following first regression equation formula is obtained, $\mathrm{Y}=14.392+$ $0.214 \mathrm{X}+0.449 \mathrm{Z}+0.509$. The meaning of the first multiple regression equation is that when all independent variables are 0 (zero), then the ICS as the dependent variable is 14.392 plus a variant that cannot be explained by the independent variable. Furthermore, the coefficient $\mathrm{X}$ is 0.214 , this indicates that if there is an increase in one independent variable OC (X) will cause an increase in one unit also on the dependent variable ICS (Y), assuming that the variable SM (Z) does not change too. Then from the regression test table above it is known that the value of $\mathrm{t}$-value $\mathrm{X}$ is 2.122 which means $\mathrm{t}$-value> 1.66 . It was also found that the significance level of $\mathrm{X}$ was 0.036 , which means it was smaller $<0.05$. Based on all of those, it can be concluded that there is a significant 
direct effect between variable $\mathrm{X}$ on $\mathrm{Y}$. So that $\mathrm{H1}$ is "received or accepted" significantly. The second multiple linear regression model in this study was tested using path analysis. Following are the results of path analysis using SM (Z) as the dependent variable.

According to the multiple regression test table of the second path analysis in this study, the following first regression equation formula is obtained, $\mathrm{Z}=$ $1.381+0.236 \mathrm{X}+0.520$. The meaning of the second multiple regression equation is that when all independent variables are 0 (zero), then the SM as the dependent variable is 1.381 plus a variant that cannot be explained by the independent variable. Furthermore, the coefficient $X$ is 0.236 , this indicates that if there is an increase in one independent variable OC (X) will cause an increase in one unit also on the dependent variable SM $(Z)$. The results of the partial $t$ statistical test between the OC $(\mathrm{X})$ variable towards the SM $(\mathrm{Z})$ variable, the $\mathrm{t}$ value was 2.957 with a significance level of 0.004. It is known that $t$ table in this study is 1.66. So this proves that 2.957> 1.66, Strengthened by the probability of a significance of $0.004<0.05$. So according to these results it can be concluded that OC has a positive and significant effect on SM, so Second hypothesis which states that organizational climate has a direct effect on the self motivation of Polyglot Indonesia members is received. $\mathrm{H2}$ is "received or accepted" significantly. The multiple linear regression analysis conducted next is to test the indirect effect of $\mathrm{X}$ on $\mathrm{Y}$ with $\mathrm{Z}$ as mediator. The Regression test that used to measure mediation variables is called the sobel test. Intermediate hypothesis testing or mediation can be done with procedures developed by Sobel in Ghazali (2013: 248). For This study used a calculator application to calculate the sobel test, The sobel test result with the application are as follows.

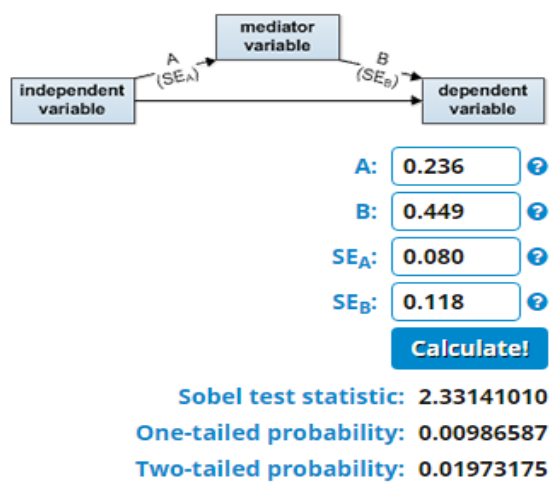

Figure 1. Sobel Test OC to ICS with SM as Intervening Variabel
Based on the results of calculations from graphic 1 , it is obtained that the result of the $t$ calculation of OC variable towards ICS variable mediated by the $\mathrm{SM}$ variable is 2.333 . While t table is 1.66 with a significance level of 0.05 . Then it can be seen that $2,331>1,659$ ( $t$ value $>t$ table), so it can be concluded that positive and significant self motivation plays a role in mediating the influence of organizational climate on intercultural communication skill among the members of Polyglot Indonesia. So it can be stated that $\mathbf{H 3}$ is "received or accepted" significantly.

According to these results, the regression model can be presented in the following Figure 2 .

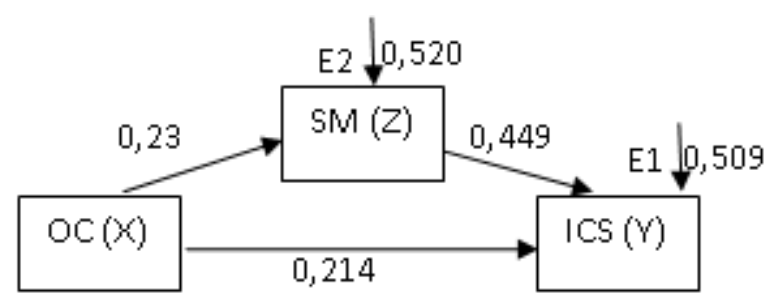

Figure 2. Regression Model

\section{Influence of Organizational Climate on Intercul- tural Communication Skill}

The results of this study indicate that organizational climate has a positive and significant influence on the development of intercultural communication skills among Polyglot Indonesia's members. This can be proven by members who state that they feel the organizational climate of Polyglot Indonesia has helped develop intercultural communication skills. According to data from a total of 110 respondents, the percentage up to $34.35 \%$ of members expressed strongly agree (very high) and $47.27 \%$ of members said they agreed (high). According to these results, most agree that the organizational climate at Polyglot Indonesia is very constructive and comfortable.

The results of this study through the $t$ test in finding out the direct influence between organizational climate variable on intercultural communication skill, it was found that $t$ was bigger than $t$ table, namely 2.122> 1.659. Furthemore, organizational climate has a significance value of $0.036<0.05$, it can be concluded that $\mathrm{H} 1$ is significantly accepted. The partial determination test result also showed that organizational climate has an influence on the intercultural communication skill by $4.12 \%$.

This shows that a comfortable, conducive, constructive and good organizational climate influences the rapid development of intercultural communication skills among Polyglot Indonesia's members. It also applies to the opposite 
The results of this study are relevant to research from Lubis (Lubis, 2015) which reveals that organizational climate greatly influences the behavior of organizational members. If the organization expects the organization's mission to be realized, then an organization should create a good and conducive organizational climate. They are also inline with Raharjo's and friends funding that stated organizational climate will make effectiveness of learning in work or organization (Raharjo, Sutarto, \& Fakhruddin, 2017). They are also inlines with Sutarto Research which stated that work climate or organization climate will improve the effectiveness of organization members learning process (Sutarto, 2017). It is also relate to Asi's finding that organizational climate has significant positive effect with employees performance as part of the work organization members (Asi, 2013). The organizational climate formed by Polyglot Indonesia so far is fairly good, so that in the end it adds to the feeling of belonging to the organization by the members, this feeling of belonging adds to the enthusiasm to be involved in the success behind the scenes of the organization's goals, in this case one of Polyglot Indonesia's goals is to help its members develop intercultural communication skill.

\section{Influence of Self Motivation on Intercultural Communication Skill}

Based on this study, it can be seen that organizational climate shows a positive and significant influence on self motivation of Polyglot Indonesia members. In the results of the study through the $t$ test in seeing the direct influence between organizational climate variable on self motivation, it was found that $\mathrm{t}$ is bigger than $t$ table, namely 2.957> 1.659. Furthemore, organizational climate has a significance value of $0.004<0.05$, it can be concluded that $\mathrm{H} 2$ is significantly accepted. In addition, the results of the partial determination test show that organizational climate has an influence on self motivation by $7.62 \%$.

This study is inline with Kusmono's (2005) research which reveals that organizational climate has a positive influence on motivation, basically individuals, especially in an organization, positive motivation is the result of the accumulation of various things, one of which is organizational climate. This relate to Awad's research findings that stated personal motive will lead the members improving their jobs satisfaction as part of organization (Awad \& Alhashemi, 2012). As a non-formal learning organization, Polyglot Indonesia tries to implement an organizational climate that supports the learning process in it. This is reflected in the self-development programs and exchange of access to information offered to its mem- bers. The organizational climate that has been applied so far has an impact on members' self motivation in taking up their role as part of Polyglot Indonesia.

\section{Influence of Organizational Climate on Intercul- tural Comunication Skill mediated By Self Moti- vation}

Referring to the results of this study, organizational climate showed that it has a positive and significant influence on the development of intercultural communication skills mediated by self motivation. This is shown by the sobel test result that produce $t$ value bigger than $t$ table, namely $2.331>1.659$. So it can be decided that there is a positive and significant influence of organizational climate on intercultural communication skill which is mediated by self motivation. So that $\mathrm{H} 3$ is accepted.

The results of this study indicate the magnitude of the indirect influence of organizational climate through self motivation as a mediating variable on intercultural communication skill of $0.236 \times 0.449=$ 0.105 or $10.59 \%$. So that the total influence of OC through SM on ICS is $0.214+0.105=0.319$ or $31.9 \%$. From these results it is clear that the self motivation of Polyglot Indonesia members increasingly makes the influence of the organizational climate successful in making intercultural communication skill of Polyglot Indonesia members more developed.

This study is relevant to Buvik's research (2015) which reveals that organizational climate plays a major role in building commitment and motivation from organizational members in realizing organizational goals. A healthy organization is an organization that is able to move its members to come together achieve organizational goals. Polyglot Indonesia itself is a non-formal learning organization that can be spelled apart from time and distance, yet its members still have strong self motivation. The influence of organizational climate will be even stronger when combined with self motivation in an effort to develop the intercultural communication skills of Polyglot Indonesia's members.

\section{CONCLUSION}

Based on the elaboration of the study in this article, it can be concluded that there is a positive and significant direct effect by the organizational climate to intercultural communication skill members of Polyglot Indonesia. This means that the organizational climate within Polyglot Indonesia is able to help its members develop themselves through learning in organization. In fact, the organizational climate has a significant influence on the 
improvement of Polyglot Indonesia members, which is characterized by good intercultural communication skill.

The next conclusion is that there is a positive and significant direct effect by the organizational climate on the self motivation of Polyglot Indonesia members. The point is that a comfortable and good organizational climate for learning in non-formal learning organizations such as Polyglot Indonesia will facilitate the learning process in it. Strong self motivation will influence the ability of Polyglot Indonesia members to develop their intercultural communication skill. The next conclusion is that there is a positive and significant indirect effect by the organizational climate to intercultural skill of Polyglot Indonesia members mediated by self motivation. It means that the organizational climate that is formed and gives a positive impression for learning will be stronger if coupled with a strong self motivation to learn. So that the aim to develop intercultural communication skills will be better to be achieved.

\section{REFERENCES}

Asi, S. P. (2013). Pengaruh Iklim Organisasi dan Burnout terhadap Kinerja Perawat RSUD dr . Doris Sylvanus Palangka Raya. Jurnal Aplikasi Manajemen, 2(3), 515-523.

Awad, T. A., \& Alhashemi, S. E. (2012). Assessing the effect of interpersonal communications on employees ' commitment and satisfaction. International Journal of Islamic and Middle Eastern Financa and Management, 5(2), 134-156.

Behery, M. H. (2009). Person / organization jobfitting and affective commitment to the organization Perspectives from the UAE. Cross Cultural Management: An International Journal, 16(2), 179-196.

Buvik, M. P., \& Tvedt, S. D. (2016). The impact of commitment and climate strength on the relationship between trust and performance in crossfunctional project teams A moderated mediation analysis. Team Performance Management, 22(3/4), 114-138.

Chang, W.-W. (2007). Cultural Competence of International Humanitarian Workers. Adult Education Quarterly, 57(3), 187-204.

Covert, H. H. (2014). Stories of Personal Agency. Journal of Studies in International Education, 18(2), 162-179.

Darmojuwono, S. (2007). Peran Stereotipe Dalam Komunikasi Lintas Budaya: Kasus IndonesiaJerman. Linguistik Indonesia, 25(1), 97-105.
Derksen, K., Caluwé, L. De, Rupert, J., Simons, R., \& Derksen, K. (2014). Assessing developmental space in teams. Team Performance Management, 20(7/8), 277-293.

Dhondt, S., Pot, F. D., Kraan, K. O., Dhondt, S., \& Pot, F. D. (2014). The importance of organizational level decision latitude for well-being and organizational commitment. Team Performance Management, 20(7/8), 307-327.

Dixon, N., \& Dixon, N. (2017). Learning together and working apart: routines for organizational learning in virtual teams. The Learning Organization, 24(3), 138-149.

Dodoiu, G. (2015). Intentions for cooperative conflict resolution in groups An application of the theory of planned behavior. Team Performance Management, 21(2015), 259-273.

Enny, M. (2015). Total Quality Management and Work Environment on Job Satisfaction and Employee Performance at PT Mount Dreams Indonesia in Gresik. The International Journal of Business \& Management, 3(4), 369-374.

French, W. (2005). Organization Development And Transformation Managing Effective Change. New York, US: Mc Graw Hill.

Fung, K., Lo, H.-T. (Ted), Srivastava, R., \& Andermann, L. (2012). Organizational cultural competence consultation to a mental health institution. Transcultural Psychiatry, 49(2), 165-184.

Furukawa, C. (2016). Dynamics of a critical problemsolving project team and creativity in a. Team Performance Management, 22(1/2), 92-10.

Gunawan, I. (2016). Pengantar Statistika Inferensial. Jakarta, Indonesia: Rajagrafindo Persada.

Kahrobaei, S. (2016). How leader - member exchange can uplift team 's energy to increase creative work involvement. Team Performance Management, 22(1/2), 75-91. Kerssen-griep, J., \& Eifler, K. (2008). When Cross-Racial Contact Transforms Intercultural Communication Competence: When Cross-Racial Contact Transforms Intercultural Communication Competence. Journal of Transformative Education, 6(4), 251-269.

Krajewski, S. (2011). Developing intercultural competence in multilingual and multicultural student groups. Journal of Research in International Education, 10(2), 137-153.

Langford, P. H., Dougall, C. B., \& Parkes, L. P. (2017). Measuring leader behaviour: evidence for a " big five" model of leadership. Leadership \& Organization Development Journal, 38(1), 126144.

Lincoln, N. D., Travers, C., Ackers, P., \& Wilkinson, A. (2002). The meaning of empowerment: the in- 
terdisciplinary etymology of a new management concept. International Journal of Management Reviews, 4(3), 271-290.

Lubis, M. S. (2015). Pengaruh Iklim Organisasi Dan Komitmen Organisasi Terhadap Pembentukan Organizational Citizenship Behavior (Ocb) Karyawan Dalam Rangka Peningkatan Kinerja. M. EJurnal Apresiasi Ekonomi, 3(2012).

Makmur, R., Kuswarno, E., Novianti, E., \& Syafirah, A. (2018). Bahasa Minang Pondok dalam Komunikasi Antarbudaya Masyarakat Tionghoa Kota Padang Society at Padang City. Jurnal Kajian Komunikasi, 6(2), 133-146.

Meslec, N., \& Graff, D. (2015). Being open matters : the antecedents and consequences of crossunderstanding in teams. Team Performance Management, 21(1/2), 6-18.

Nongkeng, H. (2012). Pengaruh Pemberdayaan , Komitmen Organisasional terhadap Kinerja dan Kepuasan Kerja Dosen ( Persepsi Dosen Dipekerjakan PTS Kopertis Wilayah IX Sulawesi di Makassar). Jurnal Aplikasi Manajemen, 10(3), 574585.

Nurwidyanti, F., Marnis, \& Marzolina. (2015). Pengaruh Pengawasan Dan Iklim Organisasi Terhadap Motivasi Dan Disiplin Kerja Pegawai Pada Kantor Biro Umum Sekretariat Daerah Provinsi Riau. Jurnal Tepak Manajemen Bisnis, VII(3), 420-436.

Nuseir, N. A. and M. T., Nusair, J. T. T., \& Rumy Arora. (2012). Study-based moderators influencing the relationship between organizational climate and employee's organization commitment. EuroMed Journal of Business, 7(2), 201-220.

Palos, R. (2016). Learning in organization. The Learning Organization, 23(1), 2-22.

Raharjo, T. J., Suminar, T., \& Mu'arifuddin. (2016). Journal of Nonformal Education. Journal of Nonformal Education, 2(1), 21-38.

Raharjo, T. J., Sutarto, J., \& Fakhruddin. (2017). Effectiveness Analysis of Non-formal Education Learning in Central Java. Advances in Social Science, Education and Humanities Research
(ASSEHR), 66(YICEMAP 2017), 108-114. Retrieved from at

Santoso, I. (2012). Pendidikan Karakter Dan Pembelajaran Bahasa Asing Berwawasan Interkultural. Jurnal Pendidikan Karakter, 2(No 1 (2012): Jurnal Pendidikan Karakter Edisi Februari 2012, TH. II, No. 1), 96-106.

Scott, J. (2012.) Teori Sosial Masalah-Masalah Pokok dalam Sosiologi. Yogyakarta, Indonesia: Pustaka Pelajar.

Sukaryanti, D. (2016). Pengaruh budaya organisasi, komitmen organisasi dan motivasi terhadap kinerja pegawai badan pusat statistik provinsi lampung. Universitas Lampung.

Sukirman, G. (2016). Kompetensi Komunikasi Antarbudaya Sebagai Sarana Membangun Kerukunan Di Masyarakat. Insani, 3(1), 11-22.

Suliman, A., \& Iles, P. (2000). Is continuance commitment beneficial to organizations? Commitment-performance relationship : a new look. Journal of Managerial Psychology, 15(5), 407-422.

Sutarto, J. (2017). Determinant Factors of The Effectiveness Learning Process and Learning Output of Equivalent Education. Advances in Social Science, Education and Humanities Research (ASSEHR), 88(Nfe 2016), 90-95. Retrieved from https://www.atlantis-press.com/

Tongo, C. I., \& Tongo, C. I. (2015). Collective work motivation in knowledge based organizations. Team Performance Management, 21(7/8), 386404.

Uha, I.N. (2013). Budaya Organisasi Kepemimpinan dan Kinerja. Jakarta, Indonesia: Prenada Media Grup.

Wasono, R., Soesanto, Samsudi, \& Sutarto, J. (2015). Improving Human Resources Through The Internalization of Cultural Values Organization. The Journal Od Educational Development, 3(2), 8390.

Wirawan. (2007). Budaya dan Iklim Organisasi Teori Aplikasi dan Penelitian. Jakarta, Indonesia: Salemba 4. 